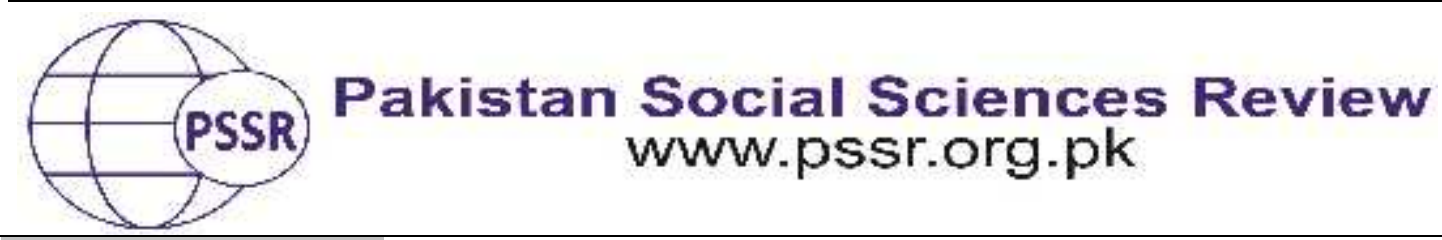

RESEARCH PAPER

\title{
Current Affairs Talk Shows on Leading TV Channels in Pakistan: Agents of Political Harmony
}

\author{
Dr Asmat Ullah ${ }^{1}$ Dr. Shabir Hussain² Dr. Muhammad Rashid Khan ${ }^{3}$
}

1. Independent Researcher and Development Expert, Islamabad, Pakistan

2. Associate Professor, Media Studies Department, Bahria University Islamabad, Pakistan

3. Assistant Professor, Institute of Communication Studies, University of the Punjab, Lahore, Punjab, Pakistan

\begin{tabular}{|c|c|}
\hline PAPER INFO & ABSTRACT \\
\hline $\begin{array}{l}\text { Received: } \\
\text { July 09, } 2020 \\
\text { Accepted: } \\
\text { September } 05,2020 \\
\text { Online: } \\
\text { September } 30,2020 \\
\end{array}$ & $\begin{array}{l}\text { In this study, the researchers have investigated the escalatory } \\
\text { and de-escalatory potential of current affairs talk shows in the } \\
\text { leading TV channels in Pakistan. The data was analyzed through } \\
\text { content analysis by applying the war and peace journalism } \\
\text { model developed by Johan Galtung. We found the five leading }\end{array}$ \\
\hline $\begin{array}{l}\text { Keywords: } \\
\text { Content Analysis, } \\
\text { Escalation, } \\
\text { Pakistan, } \\
\text { Sensationalism, } \\
\text { Talk Shows, } \\
\text { TV Channels, } \\
\text { War and Peace } \\
\text { Journalism }\end{array}$ & $\begin{array}{l}\text { talk shows produced more escalatory content like pitting the } \\
\text { political parties against each other to create more drama, } \\
\text { decontextualize the political issues and proved to be politically } \\
\text { biased. Moreover, the issues of political nature were mainly of } \\
\text { escalatory nature as compared to the non-political issues. The } \\
\text { study concludes that to create a more democratic culture in the }\end{array}$ \\
\hline $\begin{array}{l}\text { Corresponding } \\
\text { Author } \\
\text { asmatpk@yahoo.com }\end{array}$ & $\begin{array}{l}\text { country, the media should educate people in democratic } \\
\text { traditions like tolerance, political knowledge and including } \\
\text { popular perspectives on important national issues }\end{array}$ \\
\hline
\end{tabular}

\section{Introduction}

Media role in democratizing conflict has been investigated in many unconsolidated democracies (Esser\&Vreese, 2007; Mittell, 2010). While normatively media are expected to promote broader understanding in a society through debates and exploring all possible avenues, practically, their role degenerate into dysfunctions. Studies have shown a dysfunctional media create pessimism among audiences about the democratic process. Keeping in view these limitations of media, many researchers have analyzed media role in semi-democratic regimes. However, no such study is available in Pakistan to determine the function-dysfunctions of media. In this study, we attempt to investigate the role of media in Pakistan through its conflict escalation or de-escalation potential. 
After the proliferation of mass media in Pakistan most of the people spend their leisure time in front of television listening and watching the daily news and current affair programs to inform themselves about the different issues of their interest (Hussain, 2015). This consumption of television news is responsible for changing and making the perception of the audience about the world. The news channels talk shows appeared as very influential component of the modern journalism which not only shares the information about an event but also giving a well-constructed opinion about the event or issue. The talk-show journalism represents the specific development in the TV journalism providing large variety of topics with light discourse in the form of hard and soft news making journalist seductive and reliable to the home audience (Ahmad, 2010).

These talk shows are produced on daily basis on different news channels and some channels are aired live to keep the live contact of audience and giving people chance to participate in the live news event. The model of talk show take us back to the talk shows of the radio in which the audiences have the chance to participate and putting their contribution in these talk shows. After the de-generation and privatization of media channels in Pakistan gave spark to the talk shows trends which were able to grab the public attention by providing the different varieties of public interests in their show (Yaseen et al, 2018).

Talk shows of the television provided the platforms to the people and to the opinion leaders from the different way of lives. As Pakistani talk shows play vital role in politicizing the public debates and providing freedom of speech at a vast level while discussing the political issues. Talk shows of the different news channels provide different news and opinion with different agenda, the political and economic inclination of media houses also molds the policy of the channel or news programs (Ahmad, 2010).

In time of newspapers and radio talk shows, the opinions were influenced for different goals through the live talk shows on radio while articles and editorials in the newspapers were used to manage the public perception, but the news talk shows provided the journalists an opportunity to be a host and the guest of these programs, and their interpretation of an issue became more significant than the coverage of the same news story with objectivity. This overcoming representation of news anchors and journalist, made them stars of the television news providing an opportunity to the news talk shows to mine into the opinions of the audiences and providing them smooth way to the emotional pulse of their audience, regarding different issues or events (Yaseen et al, 2018; Hussain, 2015).

Discussing the talk shows in the light of above premises in this study, we tried to investigate the development and success of talk shows with in-depth focus on the framing inclination of the talk shows content. Framing concept in journalism is often used as the schema of a message interpretation allowing people to perceive or identify the message in concrete occurrences defined in its limits. In another definition the framing could be defined as making some elements salient of the 
perceived reality to audience consumable while ignoring other. These dynamics of the framing attracts the scholars from the communication and journalism and compel the news talk shows producer and developers to make complex situation to simple theme for their audiences.

\section{Literature Review}

Chauhan (2001) in his book Television and Social Transformation highlighted the importance of political talk shows in creating affinity between the viewers and media. However, it has also been divulged through this study that audience prefer entertainment programs than the rest of television genres. Kuo-Yi Wu (1990) reckoned Taiwan television role in forming social perception on sex, crime and violence, inter-personal relationships and ageing along with background and social condition exerts substantial effect. Shanahan and Morgan (1992) study of adolescents' exposure of television and its effect on family members' interaction described strengthening of adolescents and parents in a family. However, Kang (1989) did not find strong connect between high school children television programs viewing and traditional sex roles, the liberal attitudes towards dating, marriage and distorted social reality on violence and social dominance.

Although peace research in media is a recent phenomenon but the war and propaganda studies to understand the role of media is on board since $16^{\text {th }}$ century (Knightley, 2011; Carruthers, 2011). It has been observed by many scholars that use of media in war escalation sentiments remained in vogue and could be discerned through Crimean war, Spanish incursion of Cuba, cold war era, Operation Iraqi Freedom and Middle East youth revolution, (Knightly, 2004; Allan \&Zelizer, 2004; Lynch, 2008; Youngblood, 2017). The neutral or non-partisan media over the past hundred years in US also follows the war journalism approach in the name of national interest (Hammond, 2007).Wolsfeld (1997) shared the position of modern day journalists that are required by the state to follow the policy during the crises or war situation that definitely clips the freedom of press and twists its coverage in favor of war rhymes. This legacy then travels onward and even during the normal course of time the state machinery uses the media in its own favor on war peace scale of understanding.

The peace role of media is very fundamental for the prevalence of peace instead of war amongst the audience and this could be seen in the post Second World War era in Europe particularly by the radio at that time which harbored peace broadcast projects that galvanized the role of League of Nations, Howard (2003). The same is being repeated in many Asian and African conflicts to strengthen peace perspectives in the war-torn hotspots. Definitely, such media efforts diminish escalation of war and plays role in the prevalence of peace Becker (2004). The pattern of reporting we see at occasions of conflict projects 'us vs. them' which escalates the conflicting views and set stage for violence and it diminishes the chances of rapprochement between the conflicting groups (Lynch, 2013; Galtung, 1998). 
We do not know whether our talk shows anchorpersons know the scientific nature of the impact of their war laden programs or not but the researchers like Lynch and McGoldrick (2005) shared the findings that war reporting created an aura of misunderstanding and uncompromising tendencies among the warring factions and bleaks down the prospects of peace or win-win situation. Lynch and McGoldrick (2005) have set the anvil for reporters, anchors and talk show hosts that relates to their value in imparting and boosting peace journalism pertaining to their domains through which the audience may well follow the non-violent reactions/statements to the violent conflicts. Similarly, Kempf (2012) highlighted the importance of seasoned media workers in shaping the public opinion in line with peace or war standings.

Fahmy (2004) disclosed the popular news agencies portrayal of beyond veil afghan women environment during post-Taliban period which was episodic and against the mainstream ground realities in the country. King and Lester (2005) held that favorite media persons are assigned the coverage task that led to project the viewpoint of state in its coverage as that was evident in gulf war 1992 and Iraq invasion of 2003.Neumann\&Fahmy (2012) found that the major wire services like AP, AFP, Reuterfavored the American and European viewpoint while covering civil war in Sri Lanka. The study of Neumann\&Fahmy (2016) pointed out the political and cultural moorings as the galvanizing factor behind war peace reporting. Responding the same through the research study of Hoffmann, (Ed.), Hawkins, (Ed.) (2015) on post conflict nations where media functions without guards on professing war journalism tidings and that are why conflict remains alive.

Hussain (2017) on conflicts in Karachi epitomized the inclination of media towards crisis escalation and spread of sensations and toes partisan approach on political lines to project miseries of a specific political group and keeps in oblivion the sufferings of the other group reported. Similarly, Hussain and Munawar (2017) concluded about the Taliban coverage in major Pakistani newspapers from war and peace journalism perception that tilts towards war journalism. Based on the above literature, the following main question is asked in this study.

\section{Material and Methods}

In this study we selected five leading TV channel including Geo, ARY, Dunya News, Express News and Sama TV. Five primetime current affairs programs that are telecasted at $8 \mathrm{pm}$ were selected from these channels that included Capital Talk, Off the Record, KalTak, Live with Nadeem Malik, and Dunya Kamran K Sath, for the month of January of 2020. Hence a total 87 talk shows were included through a census approach.

Table 1

Table of talk shows in the study

\begin{tabular}{ccc}
\hline SN & Talk Show & On aired Programs \\
\hline 1 & Capital Talk & 17 \\
\hline
\end{tabular}




\begin{tabular}{ccc}
\hline 2 & Off the Record & 16 \\
\hline 3 & KalTak & 16 \\
\hline 4 & Dunya Kamran Khan k Sath & 21 \\
\hline 5 & Live with Nadeem Malik & 17 \\
\hline & Total & 87 \\
\hline
\end{tabular}

The time period for the study was the month of January. All the selected talk shows that were conducted during this month were part of the study. For the data analysis, an original escalatory and de-escalatory model was developed. We borrowed from Johan Galtung model of Escalatory and De-Escalatory journalism as well as the relevant scholarship on De-Escalatory journalism developed by Jake Lynch and Wilhelm Kempf. As shown in the table 1, the two key categories of escalatory approach and de-escalatory approach are both conceptually defined.

Table 2

War and peace journalism model

\begin{tabular}{ccc}
\hline Escalatory Coverage & De-Escalatory Coverage \\
\hline & Approach
\end{tabular}

Reactive approach: Instead of predicting Proactive approach: media predict a the situation before hand, media awaits situation and calls for actions before a events and then report these. situation worsens.

Lack of context: The topics selected are Context and background: the topics mere events and not linked to the reported contain proper context and background knowledge, socio-politic and history of the issues...detailed info is economic realities. (-.5) provided and all sides of a topic are reported.

Dividing: The coverage is dividing. Only Uniting: The coverage is uniting the those events, issues and topics are selected that divide the parties/groups and commonalities are ignored. (-1) parties to face mutual challenges and Win vs. lose scenario: If the political battle Win-win scenario: There are no losers, between the groups/parties is so reported all are winners. that win for one is the defeat for the other. Compromises are ridiculed. (-1)

Representation of Actors

Partiality: If the media openly sides a Impartiality: If the media does not take party in a debate. $(-1)$ side.

Not-representative: The actors invited in Representative: The actors invited in the the program are not in line with the program are in line with the topics topics selected.

Popular perspective is ignored: If on any Popular perspective is stressed: If on any given topic, the perspectives, opinions of given topic, the perspectives, opinions of common people are excluded and only common people are included and their viewpoints of politicians, bureaucrats, issues highlighted. military people are sought (-.5).

\section{Language}


Problematic Language: If the language is Serious Language: If the language is demonizing, bombastic, victimizing etc. objective, serious and terse. $(-1)$

Unit of analysis was a single question and answer. The supplementary questions were also treated as a unit of analysis. The overall dominant impression for any of the variable decided its placement in the coding sheet. All the telecast shows were retrieved from YouTube. Five coders were trained in the coding scheme. These sessions remained for a full week. One of the authors of the study coded two talk shows from each channel to check the inter-coder reliability. The overall agreement was over 80 percent for all the five channels. The level of measurement was nominal and descriptive statistics was used analyzing the data.

\section{Results and Discussion}

Table 4

Distribution of key topics in the selected talk shows

\begin{tabular}{|c|c|c|}
\hline Topics & Discussed time & Percent \\
\hline Politics & 45 & $50.56 \%$ \\
\hline Economy & 20 & $22.47 \%$ \\
\hline Terrorism & 5 & $5.61 \%$ \\
\hline Judiciary & 4 & $4.49 \%$ \\
\hline Regional/Global Issues & 13 & $14.60 \%$ \\
\hline Social/Development Issues & 2 & $2.24 \%$ \\
\hline Total & 89 & $99.97 \%$ \\
\hline $5,6 \%$ & & $\begin{array}{l}\text { Politics } \\
\text { Economy } \\
\text { - Terrorism } \\
\text { — Judiciary } \\
\text { - Regional/Global Issues } \\
\text { Social/Development } \\
\text { Issues }\end{array}$ \\
\hline
\end{tabular}

The analysis of the data shows variety of results, defining the different frames used by different programs regarding the topics which were discussed in the programs. The graphs of the analysis show that the politics is discussed in most of the programs taking $51 \%$ of the whole programs while economy is followed with $22 \%$ in the whole data. Regional issues are discussed 13 times with 15\%, Terrorism discussion is $6 \%$, Judiciary related issues are discussed $4 \%$ and Social/Development 
Issues are $2 \%$ of the whole data. The $2^{\text {nd }}$ graph of the results show the Escalatory and De-Escalatory frames of the talk show in coverage of selected topics.

Table 4

Distribution of escalatory and de-escalatory frames in the selected talk shows

\begin{tabular}{cccc}
\hline Talk Show & War Frames & Peace Frames & Total \\
\hline Capital Talk & $168(67.2 \%)$ & $82(32.8 \%)$ & $250(100 \%)$ \\
\hline Off the Record & $133(68.55 \%)$ & $61(31.44 \%)$ & $194(100 \%)$ \\
\hline KalTak & $112(58.94 \%)$ & $78(41.05 \%)$ & $190(99.99 \%)$ \\
\hline Dunya Kamran Khan k Sath & $128(65.30 \%)$ & $68(34.69 \%)$ & $196(99.99 \%)$ \\
\hline Love With Nadeem Malik & $105(55.55 \%)$ & $84(44.44 \%)$ & $189(99.99 \%)$ \\
\hline Total & $\mathbf{6 4 6}$ & $\mathbf{3 7 3}$ & $\mathbf{1 0 1 9}$ \\
\hline
\end{tabular}

The talk show Off the Record provided total 194 frames in which 68.55\% (133) were in Escalatory frames while $31.45 \%$ (61) were in De-Escalatory frames. The KAL TAK talk show provided total 190 frames in which 58.94\% (112) were framed in Escalatory frames and $41.05 \%$ (78) in De-Escalatory frames while the talk show Live With Nadeem Malik provided less frames as compared to all the other shows with numbers of 189 frames in which 55.55\% (105) are in Escalatory frames while 44.44\% (84) in De-Escalatory frames.

In the figures we see that all the programs framed most of their question in the Escalatory frames as compared to De-Escalatory frames. Capital talk program have more frames of Escalatory as compared to all the other programs. Capital talk provided $67.2 \%$ (168) escalatory frames while $32.8 \%$ (82), in De-Escalatoryframes. Following capital talk the Dunya Kamran K Sath total provided 196 frames in which $65.30 \%$ (128) while $34.69 \%$ (68) in De-Escalatoryframes.

In the context of Escalatory and De-Escalatory frames the whole data provided different results regarding different programs in which average Escalatory frames are provided by the Off the Record program while followed by Capital Talk with slim edge. While average high rate in production of De-Escalatory frames, Live With Nadeem Malik show provided more frames in their content. Analyzing the data while finding the framing of news in the selected topics of the study we found different frames of Escalatory andDe-Escalatory nature in the coverage of different issues.

Table 5

Distribution of key attributes of escalatory frames in the selected talk shows

\begin{tabular}{cccccccccc}
\hline & $\begin{array}{c}\text { Lack of } \\
\text { Context }\end{array}$ & Dividing & $\begin{array}{c}\text { Win-lose } \\
\text { scenario }\end{array}$ & $\begin{array}{c}\text { Partiality } \\
\text { Representative }\end{array}$ & $\begin{array}{c}\text { Not } \\
\text { Popular }\end{array}$ & $\begin{array}{c}\text { Problematic } \\
\text { Language }\end{array}$ & Reactive & Total \\
\hline \multirow{2}{*}{ Politics } & 4 & 22 & 26 & 29 & 17 & 26 & 28 & 25 & 177 \\
& $(2.25 \%)$ & $(12.42 \%)$ & $(14.68 \%)$ & $(16.38 \%)$ & $(9.60 \%)$ & $(14.68 \%)$ & $(15.81 \%)$ & $(14.12 \%)$ & $(99.9 \%)$ \\
\hline \multirow{2}{*}{ Economy } & 7 & 12 & 13 & 10 & 21 & 21 & 7 & 5 & 96 \\
& $(7.29 \%)$ & $(12.5 \%)$ & $(13.54 \%)$ & $(10.41 \%)$ & $(21.87 \%)$ & $(21.87 \%)$ & $(7.29 \%)$ & $(5.20 \%)$ & $(99.9 \%)$ \\
\hline \multirow{2}{*}{ Judiciary } & 10 & 14 & 13 & 16 & 8 & 13 & 5 & 10 & 89 \\
& $(11.23 \%)$ & $(15.73 \%)$ & $(14.60 \%)$ & $(17.97 \%)$ & $(8.98 \%)$ & $(14.60 \%)$ & $(5.61 \%)$ & $(11.2 \%)$ & $(99.9 \%)$ \\
\hline \multirow{2}{*}{ Terrorism } & 5 & 12 & 13 & 17 & 14 & 12 & 17 & 10 & $100(\%)$ \\
& $(5 \%)$ & $(12 \%)$ & $(13 \%)$ & $(17 \%)$ & $(14 \%)$ & $(12 \%)$ & $(17 \%)$ & $(10 \%)$ & 100 \\
\hline
\end{tabular}




\begin{tabular}{|c|c|c|c|c|c|c|c|c|c|}
\hline Local issues & $\begin{array}{c}12 \\
(14.28 \%) \\
\end{array}$ & $\begin{array}{c}3 \\
(3.57 \%)\end{array}$ & $\begin{array}{c}5 \\
(5.95 \%)\end{array}$ & $\begin{array}{c}13 \\
(15.47 \%)\end{array}$ & $\begin{array}{c}13 \\
(15.47 \%)\end{array}$ & $\begin{array}{c}8 \\
(9.52 \%)\end{array}$ & $20(23.80 \%)$ & $\begin{array}{c}10 \\
(11.9 \%)\end{array}$ & $\begin{array}{c}84 \\
(99.9) \\
\end{array}$ \\
\hline $\begin{array}{c}\text { Social } \\
\text { Development }\end{array}$ & $\begin{array}{c}6 \\
(7.31 \%)\end{array}$ & $\begin{array}{c}11 \\
(13.41 \%)\end{array}$ & $\begin{array}{c}9 \\
(10.97 \%)\end{array}$ & $\begin{array}{c}15 \\
(18.29 \%)\end{array}$ & $\begin{array}{c}9 \\
(10.97 \%)\end{array}$ & $\begin{array}{c}7 \\
(8.53 \%)\end{array}$ & $\begin{array}{c}14 \\
(17 \%)\end{array}$ & $\begin{array}{c}11 \\
(13.41 \%)\end{array}$ & $\begin{array}{c}82 \\
(99.8 \%)\end{array}$ \\
\hline Total & $\begin{array}{c}44 \\
(7 \%)\end{array}$ & $\begin{array}{c}74 \\
(11.78 \%)\end{array}$ & $\begin{array}{c}79 \\
(12.57 \%)\end{array}$ & $\begin{array}{c}100 \\
(15.92 \%)\end{array}$ & $\begin{array}{c}82 \\
(13 \%) \\
\end{array}$ & $\begin{array}{c}87 \\
(13.85 \%)\end{array}$ & $\begin{array}{c}91 \\
(14.49 \%)\end{array}$ & $\begin{array}{c}71 \\
(11.3 \%)\end{array}$ & $\begin{array}{c}628 \\
(99.9 \%)\end{array}$ \\
\hline
\end{tabular}

As per our framing analysis design, the topics were analyzed in which Escalatory andDe-Escalatory frames are further divided into subcategories. Here the results show that in total frames of the content triggered by the selected talk shows, most of the political issues are in Escalatory frames. The total number of questions related to politics in Escalatory frames are 177, in which $2.25 \%$ are covered in the Lack Of Context, $12.4 \%$ of the Escalatory frames are in Dividing category, Win -Lose Scenario is $14.6 \%$, Partiality is $16.38 \%$ ), Not Representative is $9.60 \%$, Not Popular perspective is $14.68 \%$, Problematic Language is, $15.81 \%$, and Reactive Approach is, $14.12 \%$ in the whole coverage of political issues which were framed in the Escalatory frame.

Total number of question related to the Economy which are framed in the Escalatory frames are 96 in which $7.29 \%$ are in the Lack of Context, $12.5 \%$ of the Escalatory frames are in Dividing category, Win-Lose Scenario is 13.5\%, Partiality is $10.41 \%$,Not Representative is $21.87 \%$, Not Popular perspective is $21.87 \%$, Problematic Language is, $7.29 \%$, and Reactive Approach is, $5.20 \%$ in the whole coverage of Issues related to Economy which were framed Escalatory.

In the topic of Judiciary total 89 stories are framed in the Escalatory frames in which $11.23 \%$ of units covered in the Lack Of Context, $15.73 \%$ of the Escalatory frames are in Dividing category, Win-Lose Scenario is $14.60 \%$, Partiality is, $17.97 \%$, Not Representative is $8.98 \%$, Not Popular perspective is $14.60 \%$, Problematic Language is, $5.60 \%$, and Reactive Approach is, $11.2 \%$ in the whole coverage of Issues related to Judiciary which were framed Escalatory.

Terrorism stories presented in the Escalatory frames are 100 in numbers in the whole talk shows and further division of these frames show that $5 \%$ falls in the category of Lack of Context, $12 \%$ in the Dividing, $13 \%$ in Win-Lose, 17\% in Partiality, $14 \%$ in Not-Representative, $12 \%$ in Not-Popular, 17\% in Problematic Language and $10 \%$ in Reactive.

Local Issues are framed 84 time in the Escalatory frames in which $14.28 \%$ in the Lack Of Context, 3.57\% of the Escalatory frames are in Dividing category, Win Lose Scenario is $5.95 \%$, Partiality is, $15.47 \%$, Not Representative is $15.47 \%$, Not Popular perspective is $9.52 \%$, Problematic Language is, $23.80 \%$, and Reactive Approach is, $11.9 \%$ in the whole coverage of Local Issues which were framed Escalatory.

In the category of Social/Development Issues total number of frames which are presented Escalatory are 82 and in further categorization of Escalatory frames 
$7.31 \%$ of units covered in the Lack Of Context, $13.41 \%$ of the Escalatory frames are in Dividing category, Win -Lose Scenario is $10.97 \%$, Partiality is, $18.29 \%$, Not Representative is $10.97 \%$,Not Popular perspective is $8.53 \%$, Problematic Language is, $14 \%$, and Reactive Approach is, $13.41 \%$ in the whole framed in the war.

Following the analysis model the De-Escalatory frames are also generated from the analyzed data which also provided different frames while covering the selected topics of the study.

Table 6

Distribution of key de-escalatory frames in the selected talk shows

\begin{tabular}{|c|c|c|c|c|c|c|c|c|c|}
\hline & $\begin{array}{c}\text { Context \& } \\
\text { Backgrounc }\end{array}$ & Uniting & $\begin{array}{l}\text { Win-Win } \\
\text { scenario }\end{array}$ & Impartiality & Representative & $\begin{array}{c}\text { Popular } \\
\text { Perspective }\end{array}$ & $\begin{array}{c}\text { Serious } \\
\text { Languag }\end{array}$ & $\begin{array}{l}\text { Proactive } \\
\text { Approach }\end{array}$ & Total \\
\hline Politics & $\begin{array}{c}11 \\
(22.44 \%)\end{array}$ & $\begin{array}{c}5 \\
(10.20 \%)\end{array}$ & $\begin{array}{c}3 \\
(6.12 \%)\end{array}$ & $\begin{array}{c}4 \\
(8.16 \%)\end{array}$ & $\begin{array}{c}10 \\
(20.40 \%)\end{array}$ & $\begin{array}{c}3 \\
(6.12 \%)\end{array}$ & $\begin{array}{c}8 \\
(16.32 \%\end{array}$ & $\begin{array}{c}5 \\
(10.20 \%\end{array}$ & $\begin{array}{c}49 \\
(99.9 \%)\end{array}$ \\
\hline Economy & $\begin{array}{c}10 \\
(17.85 \%)\end{array}$ & $\begin{array}{c}8 \\
(14.28 \%)\end{array}$ & $\begin{array}{c}7 \\
(12.5 \%)\end{array}$ & $\begin{array}{c}6 \\
(10.71 \%)\end{array}$ & $\begin{array}{c}6 \\
(10.71 \%)\end{array}$ & $\begin{array}{c}3 \\
(5.35 \%)\end{array}$ & $\begin{array}{c}12 \\
(21.42 \%)\end{array}$ & $\begin{array}{c}4 \\
(7.14 \%)\end{array}$ & $\begin{array}{c}56 \\
(99.9 \%)\end{array}$ \\
\hline Judiciary & $\begin{array}{c}8 \\
(12.90 \%)\end{array}$ & $\begin{array}{c}10 \\
(16.12 \%)\end{array}$ & $\begin{array}{c}10 \\
(16.12 \%)\end{array}$ & $\begin{array}{c}8 \\
(12.90 \%)\end{array}$ & $\begin{array}{c}4 \\
(6.45 \%)\end{array}$ & $\begin{array}{c}6 \\
(9.67 \%)\end{array}$ & $\begin{array}{c}14 \\
(22.5 \%)\end{array}$ & $\begin{array}{c}2 \\
(3.22 \%)\end{array}$ & $\begin{array}{c}62 \\
(98.9 \%)\end{array}$ \\
\hline Terrorism & $\begin{array}{c}6 \\
(7.89 \%)\end{array}$ & $\begin{array}{c}14 \\
(18.42 \%)\end{array}$ & $\begin{array}{c}11 \\
(14.47 \%)\end{array}$ & $\begin{array}{c}12 \\
(15.78 \%)\end{array}$ & $\begin{array}{c}8 \\
(10.52 \%)\end{array}$ & $\begin{array}{c}12 \\
(15.78 \%)\end{array}$ & $\begin{array}{c}4 \\
(5.26 \%)\end{array}$ & $\begin{array}{c}9 \\
(11.84 \%)\end{array}$ & $\begin{array}{c}76 \\
(99.9 \%)\end{array}$ \\
\hline Local issues & $\begin{array}{c}14 \\
(15.55 \%) \\
\end{array}$ & $\begin{array}{c}11 \\
(12.22 \%) \\
\end{array}$ & $\begin{array}{c}13 \\
(14.44 \%) \\
\end{array}$ & $\begin{array}{c}18 \\
(20 \%) \\
\end{array}$ & $\begin{array}{c}12 \\
(13.33 \%) \\
\end{array}$ & $\begin{array}{c}6 \\
(6.66 \%) \\
\end{array}$ & $\begin{array}{c}8 \\
(8.88 \%) \\
\end{array}$ & $\begin{array}{c}8 \\
(8.88 \%) \\
\end{array}$ & $\begin{array}{c}90 \\
(99.9 \%) \\
\end{array}$ \\
\hline $\begin{array}{c}\text { Social } \\
\text { Developmen }\end{array}$ & $\begin{array}{c}5 \\
(8.47 \%)\end{array}$ & $\begin{array}{c}9 \\
(15.25 \%)\end{array}$ & $\begin{array}{c}5 \\
(8.47 \%)\end{array}$ & $\begin{array}{c}12 \\
(20.33 \%)\end{array}$ & $\begin{array}{c}6 \\
(10 \%)\end{array}$ & $\begin{array}{c}12 \\
(20.33 \%)\end{array}$ & $\begin{array}{c}4 \\
(6.77 \%)\end{array}$ & $\begin{array}{c}6 \\
(10 \%)\end{array}$ & $\begin{array}{c}59 \\
(99.9 \%)\end{array}$ \\
\hline Total & $\begin{array}{c}54 \\
(13.77 \%) \\
\end{array}$ & $\begin{array}{c}57 \\
(14.54 \%) \\
\end{array}$ & $\begin{array}{c}49 \\
(12.5 \%)\end{array}$ & $\begin{array}{c}60 \\
(15.30 \%) \\
\end{array}$ & $\begin{array}{c}46 \\
(11.73 \%) \\
\end{array}$ & $\begin{array}{c}42 \\
(10.71 \%) \\
\end{array}$ & $\begin{array}{c}50 \\
(12.75 \%) \\
\end{array}$ & $\begin{array}{c}34 \\
(8.67 \%) \\
\end{array}$ & $\begin{array}{c}392 \\
(99.92 \%)\end{array}$ \\
\hline
\end{tabular}

Following the explanation of the previous graph and comparatively presenting the figures of the Escalatory versus De-Escalatory frames in the selected topics of the study, starting from Political Frames which are total 49 in the different categories of De-Escalatory frames. $22.44 \%$ in the whole De-Escalatory frames of politics fall in the category of Context and Background, $10.20 \%$ frames are in Uniting, Win-win Scenario is 6.12\%, Impartiality is $8.16 \%$, Representative is $20.40 \%$, Popular Perspective is $6.12 \%$, Serious Language is $16.32 \%$, and the Proactive Approach is $10.20 \%$.

De-Escalatory frames in the topic of Economy related issue are total 56 in the different categories of De-Escalatory frames. $17.85 \%$ in the whole De-Escalatory frames of Economy fall in the category of Context and Background, $14.28 \%$ frames are in Uniting, Win-win Scenario is $12.5 \%$, Impartiality is $10.71 \%$, Representative is $10.71 \%$, Popular Perspective is $5.35 \%$, Serious Language is $21.42 \%$, and the Proactive Approach is $7.14 \%$.

Judiciary Frames which are total 62 in the different categories of DeEscalatory frames. Here, $12.90 \%$ in the whole De-Escalatory frames of Judiciary falls in the category of Context and Background, 16.12\% frames are in Uniting, Win-win Scenario is $16.12 \%$, Impartiality is $12.90 \%$, Representative is $6.45 \%$, Popular Perspective is $9.67 \%$, Serious Language is $22.5 \%$, and the Proactive Approach is $3.22 \%$. 
Frames related to Terrorism are total 76 in the different categories of DeEscalatory frames. Here, $7.89 \%$ in the whole De-Escalatory frames of Terrorism falls in the category of Context and Background, $18.42 \%$ frames are in Uniting, Win-win Scenario is $14.47 \%$, Impartiality is $15.78 \%$, Representative is $10.52 \%$, Popular Perspective is $15.78 \%$, Serious Language is $5.26 \%$, and the Proactive Approach is $11.84 \%$.

Local Issues are framed 76 in the different categories of De-Escalatory frames in which, $15.55 \%$ in the whole De-Escalatory frames of Local Issues falls in the category of Context and Background, $12.22 \%$ frames are in Uniting, Win-win Scenario is $14.44 \%$, Impartiality is $20 \%$, Representative is $13.33 \%$, Popular Perspective is $6.66 \%$, Serious Language is $8.88 \%$, and the Proactive Approach is also $8.88 \%$.

Social/Development issues are framed59times in the different categories ofDe-Escalatory frames in which, $8.47 \%$ in the whole De-Escalatory frames of Social and Development issues falls in the category of Context and Background, 15.25\% frames are in Uniting, Win-win Scenario is $8.47 \%$, Impartiality is $20.33 \%$, Representative is $10 \%$, Popular Perspective is $20.33 \%$, Serious Language is $6.77 \%$, and the Proactive Approach is $10 \%$.

\section{Conclusion}

This study tried to investigate the escalatory and de-escalatory potential of current affairs talk shows in Pakistan. The study investigated that most of the content in the talk shows are framed in the escalatory frames. This is in line with previous studies that most of the Pakistani media framing of conflicts is escalatory that provided further ignition to conflicts rather than finding solutions through consensus.

Identifying the most discussed topics in the talk show the gallop survey report 2019 concluded that politics is the most discussed topic in the talk shows, now these findings are also supporting the current study. The result show that politics is most discussed topic in the talk shows with highest frequency in the Escalatory frames, while in De-Escalatory frames politics falls in the lowest degree. Terrorism, Economy, Judiciary, Local Issue and Social/Development issues get their position after the political issues in the Escalatory frames.

The De-Escalatory Frames in the talk shows are also found in selected topics in which most of the frames are used while covering the Local Issues as compared to other topics which were selected for the study. The high numbers of frames in DeEscalatory in talk shows, show that talk shows are framing local issues differently as compared to news stories in which usually local issues are presented. The Local Issues are followed by Terrorism, Judiciary, Social/Development, Economy and Politics. 


\section{References}

Allan, S., \& Zelizer, B. (2004). Rules of engagement. Reporting war: Journalism in wartime, 3-21.

Ahmed, R. (2010). Role of news talk shows in creating political efficacy among youth. Social Sciences Review of Pakistan, 30.

Becker, J. (2004). Contributions by the Media to Crisis Prevention and Conflict Settlement. Conflict \& Communication Online, 3(1/2), 1-17.

Baresch, B., Hsu, S. H., \& Reese, S. D. (2010). The power of framing: New challenges for researching the structure of meaning in news. The Routledge Companion to News and Journalism. London: Routledge, 637-647.

Conniff, R. (2002). Patriot games. The Progressive, 66(1), 14.

Changkamol, W. (2013). Journalism and the Path to Peace in the South of Thailand.

Chauhan, K. (2001). Television and Social Transformation: A Study in Mass Communication. Sarup\& Sons.

Carruthers, S. L. (2011). The media at war. Macmillan International Higher Education.

Dimitrova, D. V., \&Strömbäck, J. (2008). Foreign policy and the framing of the 2003 Iraq War in elite Swedish and US newspapers. Media, War \& Conflict, 1(2), 203-220.

Esser, F., \& De Vreese, C. H. (2007). Comparing young voters' political engagement in the United States and Europe. American behavioral scientist, 50(9), 1195-1213.

Fahmy, S. (2004). Picturing Afghan women: A content analysis of AP wire photographs during the Taliban regime and after the fall of the Taliban regime. Gazette (Leiden, Netherlands), 66(2), 91-112.

Galtung, J. (1998). After Violence: 3R, Recon struction, Reconciliation, Resolution. Coping With Visible and Invisible Effects of War and Violence. Princeton, NJ: TRANSCEND.

Hammond, P. (2007). Media, war and postmodernity. Routledge.

Howard, M. M., \& Howard, M. M. (2003). The weakness of civil society in post-communist Europe. Cambridge University Press.

Hoffmann, J. (Ed.), Hawkins, V. (Ed.). (2015). Communication and Peace, London: Routledge.

Hussain, S. (2017). Analyzing the war-media nexus in the conflict-ridden, semi-democratic milieu of Pakistan. Media, War \& Conflict, 10(3), 273-292. 
Hussain, S., \&Munawar, A. (2017). Analysis of Pakistan Print Media Narrative on the War on Terror. International Journal of Crisis Communication, 1(1), 38-47.

Izadi, F., \&Saghaye-Biria, H. (2007). A Discourse Analysis of Elite American Newspaper Editorials: The Case of Iran's Nuclear Program. Journal of Communication Inquiry, 31(2), 140-165.

King, C., \& Lester, P. M. (2005). Photographic Coverage during the Persian Gulf and Iraqi Wars in Three US Newspapers. Journalism \& Mass Communication Quarterly, 82(3), 623-637.

Kempf, W., \& Thiel, S. (2012). On the Interaction between Media Frames and Individual Frames of the Israeli-Palestinian Conflict. Conflict $\mathcal{E}$ Communication, 11(2).

Snow, N., \&Kamalipour, Y. R. (Eds.). (2004). War, Media, and Propaganda: A Global Perspective. Rowman\& Littlefield.

Kuo, Yi-Wu. (1990). Television and the value system of Taiwan's adolescents - A cultivation analysis. Ph.D Dissertation, University of Massachusetts. Dissertation Abstract Inter-National, Vol. 50 No. 12 pp. 3783 A

Knightley, S. P., McGregor, W. L., \& Peters, G. N. (2011). U.S. Patent No. 7,972,984. Washington, DC: U.S. Patent and Trademark Office.

Lynch, J. (2013). Is peace journalism feasible? Pointers for research and media development. Ethical Space, 10(2/3), 15-24.

Lynch, J., \&McGoldrick, A. (2005). Peace journalism: a global dialog for democracy and democratic media. Democratizing global media: One world, many struggles, 269-312.

Lynch, J. (2008). Debates in Peace Journalism. Sydney University Press.

Lee, S. T. (2010). Peace journalism: Principles and structural limitations in the news coverage of three conflicts. Mass Communication and Society, 13(4), 361-384.

Mittell, J. (2010). Television and American culture. Oxford University Press, USA.

Neumann, R., \&Fahmy, S. (2012). Analyzing the spell of war: A war/peace framing analysis of the 2009 visual coverage of the Sri Lankan civil war in western newswires. Mass Communication and Society, 15(2), 169-200.

Neumann, R., \&Fahmy, S. (2016). Measuring journalistic peace/war performance: An exploratory study of crisis reporters' attitudes and perceptions. International Communication Gazette, 78(3), 223-246. 
Shanahan, James and Michael Morgan (1992). Adolescents, families and television in five countries- Implications for cross-cultural educational research, Journal of Educational Television, Vol 18 Issue 1 pp. 35-55.

Tolson, A. (Ed.). (2001). Television talk shows: discourse, performance, spectacle. Routledge.

Wolsfeld, G. (1997). Media and Politic Conflict. News from the Middle East, Londres, Cambridge University.

Youngblood, S. (2017). Kenyan media test peace journalism principles. Peace Review, 29(4), $440-442$.

Yaseen, M., Mamdani, K. F., \& Siddiqui, M. (2018). The Role Of Political Talk Shows In Raising Political Awareness Among Youth: A Case Study Of University Of KarachI. International Journal of Humanities and Cultural Studies (IJHCS) ISSN 23565926, 5(3), 90-108. 